\title{
MOLECULAR DIVERSITY IN SELECTED LANDRACES RESISTANCE TO BLAST PATHOGEN (PYRICULARIA GRISEA COOKE EX SACC.) OF PEARL MILLET (PENNISETUM GLAUCUM (L.) R. BR.) GERMPLASM FROM NORTHERN NIGERIA
}

\author{
Abdulhakeem ABUBAKAR ${ }^{1 *}$, Olamide Ahmed FALUSI ${ }^{1,2}$, Matthew Omoniyi \\ ADEBOLA $^{1}$, Oladipupo Abdulazeez Yusuf DAUDU ${ }^{1}$, Amina Jummai SALAUDEEN ${ }^{3}$ \\ ${ }^{1}$ Department of Plant Biology, Federal University of Technology, Minna - Nigeria \\ ${ }^{2}$ Department of Biological Sciences, Ibrahim Badamasi Babangida University, Lapai - Nigeria \\ ${ }^{3}$ Department of Crop Production, Federal University of Technology, Minna - Nigeria \\ ${ }^{*}$ Corresponding author. E-mail: abuakim2007@gmail.com
}

\begin{abstract}
Germplasm collection and sourcing for resistant genotypes among the available landraces through characterization and quantification of genetic diversity is essential for introgression in plant breeding programs. Therefore, study on molecular diversity of pearl millet (Pennisetum glaucum) landraces was carried out to characterize the crop accessions for resistance to blast pathogen as well as identify elite accession(s) for the crop improvement. Thirty five (35) pearl millet germplasm were collected from the major cultivated states in Nigeria and were screened for blast resistant genotypes on the field using a Randomized Complete Block Design (RCBD). Selected potentially resistant accessions for blast resistant were further confirmed under screen house condition and evaluated for genetic diversity using random amplified polymorphic DNA-PCR. Out of the 35 accessions screened for blast, 14 were potentially resistant to blast disease (with disease score of $\leq 3.9$ on 1-9 scale). Further nursery screening of the potentially resistant accessions to blast showed that NS-YEL-02 was the most highly resistant followed by NG-ZB-01 with severity disease score of 0.00 and 0.33 , respectively. Molecular diversity of selected 14 resistant and 2 susceptible accessions using random amplified polymorphic DNA showed no specific marker for resistant and susceptible accession to the disease. A total of fifty nine (59) amplified fragment bands with 10 DNA primers was generated, of which 53 (89.83\%) were polymorphic and 6 (10.17\%) were monomorphic. Genetic similarity among the accessions varied from 0.18 to 1.44 with an average gene diversity value of 0.74 . Clustered dendrogram of the 16 accessions revealed two major cluster groups; two susceptible (KD-CK-01 and NGB501) accessions with similarity coefficient 1.14, and 14 resistant accessions. Clustering of the selected landraces base on resistance and susceptibility by RAPD techniques, indicate its possibility for indirect selection of blast resistant genotypes for the crop. The high resistance and clustering of NS-YEL-02 singly in a group by the makers indicate the uniqueness and its prospect for selection, as elite parent accessions in blast disease resistance breeding programs of pearl millet.
\end{abstract}

Keywords: blast pathogen, molecular diversity, pearl millet, RAPD, resistant.

\section{Introduction}

Genetic improvement of crop species mainly depends on the extent of variability for economically important traits present in the gene pool [SINGH \& al. 2013]. Pearl millet, Pennisetum glaucum (L.) R. Br. - Family Poaceae is endowed with enormous genetic variability for various morphological traits, yield components, adaptation and quality traits which have accumulated over a long century [SHAH \& al. 2012]. This huge variability had not been well exploited for its improvement, with the crop been attacked by many diseases 
such as blast, downy mildew, ergot, rust and smut. Among these, leaf blast caused by Pyricularia grisea had been identified as a major problem with a serious threat to pearl millet productivity [PAWAR \& al. 2016]. In Northern Nigeria, where the crop is mainly produced, its production had been reported to be undermined and yield is usually uncertain due to leaf blast constraints [ABDULLAHI \& al. 2006; SHARMA \& al. 2013; AZARE \& al. 2020]. However, pearl millet landraces had been reported to be rich sources of resistance to various biotic and abiotic stresses as well as traits for improving grain and fodder quality [KHAIRWAL \& al. 2007]. This resistance advantage of the local landraces has been exploited only to a limited extent in a very unsystematic manner for the crop improvement in Nigeria [ANGARAWAI \& al. 2016].

According to OBIDIEGWU \& al. (2014), developing of superior, high yielding and biotic tolerance cultivars could be achieved through characterization and understanding of genetic variations available in the germplasm. The use of molecular markers for quantification of genetic diversity present within cultivars had been reported to be of great importance in improving inheritable disease resistance in crop through selection of efficient and diverse combination of parents [ABOU-TALEB \& al. 2010]. Random Amplified Polymorphic DNA (RAPD) marker technique has been effectively used to detect genetic variation among variant resistant genotypes in different crop species such as groundnut genotypes to foliar diseases [MONDAL \& al. 2005], wild and cultivated potato (Solanum demissum) variety to late blight [ABOU-TALEB \& al. 2010], characterized resistant and susceptible pearl millet to downy mildew [MAHATMA \& al. 2011] without prior sequence information. Therefore, collection of germplasm, characterization and quantification for genetic diversity among the selected resistant landraces was carried out using RAPD markers.

\section{Material and methods}

\section{Collection of Germplasm}

A total of thirty five (35) pearl millet accessions were collected from the major growing states (Adamawa, Gombe, Jigawa, Kano, Nasarawa, Niger, Kaduna, Sokoto, Taraba, and Zamfara) in the Northern Nigeria; these included twenty five (25) landraces from farmers through direct contact and 10 landraces from National Centre for Genetic Resources and Biotechnology (NACGRAB), Ibadan, Nigeria.

\section{Field screening for blast resistance}

Field screening of the collected landraces was carried out for selection of potential resistant accessions to blast disease, using Randomized complete Block Design (RCBD) with a total of 25 plants per plot and 75 plants per accession in 3 blocks. The evaluation was done by examining 10 randomly selected plants per plot for blast symptoms and the percentage disease incidence (PDI) was calculated LUBADDE \& al. (2014). The leaf blast severity of each accession was scored on plot basis using a scale of 0-9 developed by IRRI and reviewed by THAKUR \& al. (2011) (Table 1).

$$
\text { PDI }(\%)=\left(\frac{\text { Total Number of Disease Plant }}{\text { Total Number of Selected Plants Per Plot }}\right) \times 100
$$




\section{Isolation, Identification and Pathogenicity of Blast Pathogen}

Isolation and identification of blast pathogen was done using modified methods of THAKUR \& al. (2009a) and MANANDHAR \& al. (2016). Infected tissues (leaf and node) were obtained from blast susceptible plants in the field and culture on potato dextrose agar (PDA). Pure cultures of the isolate were prepared and identified base on culture morphology and microscopic characteristics of the spores and mycelia.

Pathogenicity of the identified fungi isolate ( $P$. grisea) was carried by sprayinoculation of potted seedling (10 seedlings per pot) of susceptible accession (KD-JB-01) with aqueous conidial suspension $\left(1 \times 10^{5}\right.$ conidia/mL) at fifteenth (15) days after planting using mineral oil (glycerin) as carrier. The set-up was incubated at screen house temperature $27 \pm 3{ }^{\circ} \mathrm{C}$ for 24 hour; after which the seedlings were exposed to relative humidity of above $90 \%$ under mist for 7 days. The experiment was replicated four times and monitored for the development of blast symptoms for re-isolation of the pathogen [SHARMA \& al. 2013].

Table 1. Blast severity (0-9 grade) disease rating scale used for Pearl Millet.

\begin{tabular}{|c|c|c|}
\hline Grade & Disease severity & Host response \\
\hline 0 & No lesions & Highly Resistant \\
\hline 1 & Small brown specks of pin point size & Resistant \\
\hline 2 & Larger brown specks & Moderately resistant \\
\hline 3 & $\begin{array}{l}\text { Small, roundish to slightly elongated, necrotic spots, about } 1 \text { - } \\
2 \mathrm{~mm} \text { in diameter with brown margin }\end{array}$ & Moderately resistant \\
\hline 4 & $\begin{array}{l}\text { Typical blast lesions usually confined to the area between } \\
\text { main veins, covering }<5 \% \text { of the leaf area }\end{array}$ & Moderately susceptible \\
\hline 5 & Typical blast lesions covering $6-10 \%$ of the leaf area & Moderately susceptible \\
\hline 6 & Typical blast lesions covering $11-25 \%$ of the leaf area & Susceptible \\
\hline 7 & Typical blast lesions covering $26-50 \%$ of the leaf area & Susceptible \\
\hline 8 & $\begin{array}{l}\text { Typical blast lesions covering } 51-75 \% \text { of the leaf area and } \\
\text { many leaves dead }\end{array}$ & Highly susceptible \\
\hline 9 & $\begin{array}{l}\text { Typical blast lesions covering } 76 \% \text { and above of the leaf area } \\
\text { and all leaves dead }\end{array}$ & Highly susceptible \\
\hline
\end{tabular}

Source: THAKUR \& al. (2011).

\section{Nursery Screening for Blast Resistance}

The selected potentially resistant accessions on the field were planted in experimental bags of $30 \mathrm{~cm}$ diameter (10 seeds/pot) filled with 15 liters of mixed sterilized sand-loamy soil and manure (3:1 weight/weight). The bags were labeled properly and arranged in a completely randomized design (CRD) with three replicate per accession in a nursery and maintained at temperature of $27 \pm 3{ }^{\circ} \mathrm{C}$ in a screen house. The germinated seeds at 14 days-old; were spray-inoculated with an aqueous conidial suspension $\left(1 \times 10^{5}\right.$ 
conidia/mL) using mineral oil (glycerin) as carrier and covered with transparent polyethylene bags to prevent cross contamination. The seedlings were incubated at $27 \pm 3{ }^{\circ} \mathrm{C}$ for 24 hour and after which polyethylene bags were removed; exposed to relative humidity of above $90 \%$ under mist for 7 days. The seedlings were monitored for development of blast symptoms and severity of the disease was scored and recorded on twenty (20) plants for each accession between 8 to 21 days after inoculation using a progressive scale of 0-9 developed by THAKUR \& al. (2011) (Table 1).

\section{Molecular evaluation}

The molecular analysis was carried out at Bio-Science Laboratory, International Institute of Tropical Agriculture (IITA), Ibadan, Nigeria.

\section{DNA extraction}

The DNA extraction from fresh young leaf (2 weeks old) of the 16 nursery screened pearl millet accessions was carried out using Cetyl Trimethyl Ammonium Bromide (CTAB) procedure as described by DAUDU \& al. (2016) with slight modifications. One hundred milligram (100 mg) of the leaf sample (for each accession) was ground in liquid nitrogen to a fine powder and transferred into $2.0 \mathrm{ml}$ Eppendorf tube. 700 $\mu \mathrm{L}$ of pre-heated DNA extraction buffer (100 mM tris-HCl (pH 8.0), $20 \mathrm{mM}$ EDTA, $1.4 \mathrm{M}$ $\mathrm{NaCl}, 2 \% \mathrm{CTAB}$, and 1\% 2-mercaptoethanol) was added and vortex thoroughly for 10 minutes to obtain even suspension. The samples were incubated at $65{ }^{\circ} \mathrm{C}$ for 30 minutes with intermittent shaking and cooled for 2 minutes. A volume of $750 \mu \mathrm{l}$ of chloroformisoamyl alcohol mixture (24:1) was added to each sample tubes and centrifuged at 12,000 rpm for 10 min (Sigma centrifuge model 4K15C) to obtain the protein. The separated aqueous and viscous supernatant was transferred to a freshly labelled eppendorf tube. Icecold isopropanol $(500 \mu \mathrm{l})$ was added to an approximately $400 \mu \mathrm{l}$ of the supernatant. The prepared samples were gently mixed and incubated in $-20{ }^{\circ} \mathrm{C}$ for 1 hour to precipitate the nucleic acid (DNA). The samples were centrifuge at 12,000 rpm for 10 minutes and the supernatants were decanted to the last drop in a fume chamber leaving the DNA in the tubes. The DNA was washed in 70\% ethanol and vacuum dried for 10 minutes. Degradation of the co-isolated RNA was achieved by re-suspending DNA pellet in $200 \mu$ l of TE buffer containing $3 \mu \mathrm{l}$ of RNase $(40 \mathrm{mg} / \mu \mathrm{l})$ mixed properly and incubated at room temperature for 30 minutes.

RNA was remove from each tube after incubation period, by adding Chloroform:isoamylalcohol (24:1) mixture and centrifuged at 12,000 rpm for 10 minutes. The aqueous layer containing the DNA was transferred to fresh tubes and $15 \mu \mathrm{l}$ of $3 \mathrm{M}$ sodium acetate ( $\mathrm{pH} 5.2)$ and $300 \mu \mathrm{l}$ (2 volume) of absolute ethanol were added; incubated at $-20{ }^{\circ} \mathrm{C}$ for 30 minutes and centrifuged at $12,000 \mathrm{rpm}$ for 10 minutes. The supernatant was decanted carefully, and $200 \mu \mathrm{l}$ of $70 \%$ ethanol was added to the tubes; centrifuged at 12,000 rpm for 5 minute to obtain the DNA pellets by carefully decanting the supernatant from each tube and vacuum dried for 10 minutes. The quality of the DNA was checked on $0.8 \%$ agarose gel electrophoresis and quantified with Nanodrop Spectrophotometer (ND-1000) before storage at $-20{ }^{\circ} \mathrm{C}$.

\section{DNA amplification}

Ten set of randomly amplified DNA primers were used for amplification. The conditions reported by WILLIAMS \& al. (1990) for creating RAPD markers by PCR in pearl millet template DNA were used. PCR Amplification reaction was carried out in a $25 \mu \mathrm{l}$ reaction volume which contained $2.0 \mu \mathrm{l}$ of DNA template, $2.5 \mu \mathrm{l}$ of $10 \mathrm{mM}$ Tris-HCl $(\mathrm{pH}$ 8.0), $50 \mathrm{mM} \mathrm{KCl}, 2.0 \mathrm{mM} \mathrm{MgCl} 2,2.0 \mu \mathrm{l}$ of $2.5 \mathrm{mM}$ dNTPs, $0.2 \mu \mathrm{l}$ of Taq polymerase and 
Abdulhakeem ABUBAKAR \& al.

$10 \mu \mathrm{l}$ of RAPD primer in a thermocycler model 9600 . The reaction was conducted in 40 cycles and each cycle consists of denaturation at $94^{\circ} \mathrm{C}$ for $15 \mathrm{sec}$, followed by annealing at $37{ }^{\circ} \mathrm{C}$ for $40 \mathrm{sec}$ and primer extension at $72{ }^{\circ} \mathrm{C}$ for $60 \mathrm{sec}$. Different levels of annealing temperatures (37, 42 and $72{ }^{\circ} \mathrm{C}$ ) and number of cycles (45 and 55 cycles) were used for the amplification conditions. The products were then amplified on $2 \%$ agarose gels using 0.2 $\mu \mathrm{g} \mathrm{ml}{ }^{-1}$ ethidium bromide stains and ran at 80 Volts for 4 hrs. The result was visualized under UV light, estimated using 50 base pair (bp) standard size marker and the fragment band photographs were then taken.

\section{Data analysis}

The data obtained on disease incidence were expressed in percentage and that of severity were subjected to analysis of variance (ANOVA) to determine the level of significance within the means using SPSS software version 18. Analyses of the Molecular data were done using the maximum composite likelihood model. The analysis involved 16 nucleotide sequences. Each band in the RAPDs profile was taken as an independent locus with two alleles. The bands produced for the primer were scored one (1) for presence or zero (0) for absence manually and a binary matrix was generated for further analysis. Evolutionary analyses were conducted in MEGA6 [TAMURA \& al. 2013].

\section{Results}

\section{Field evaluation for blast infection}

Field evaluation of the 35 accessions for blast resistance showed that there was significant different $(p<0.05)$ in level of resistance of the genotypes to blast infection. Fourteen accessions equivalent to $40.00 \%$ of the total accessions are potentially resistance to the blast infection with disease score ranged of 0.78 to 3.50. Accessions NS-GIN-03 (0.78), NS-YEL-02 (0.80) and NG-ZC-01 (0.96) were highly resistant (HR), NG-ZB-01 (1.50) and NG-ZA-08 (1.90) were resistant (R) and nine (9) of the accessions were moderately resistant (MR) (Table 2). A total of $60.00 \%$ of the accessions were susceptible to blast infection with highest susceptible accession being KD-JB-01 (7.70) and least moderately susceptible as NS-GAN-05 (4.33). In terms of potential disease incidence (PDI), KD-JB-01 was the most infected genotype with the value of $96.25 \%$ and NS-GIN-03 (11.25\%) being the least.

\section{Screen house evaluation for blast infection}

The result of screen house evaluation of the fourteen selected potential resistance and two susceptible (KD-CK-01 and NGB501) accessions as check is presented in Table 3. Out of the fourteen selected potential resistance accessions, nine (9) of the accession proved to be blast resistance with NS-YEL-02 being the most resistance to the pathogen with disease severity score of 0.00 when compared to the field value of 0.80 . This is followed by accession NS-YEL-07 (0.67) and the least resistance being NS-JIL-01 with the value 3.33 compared to 3.30 on the field (Table 3). The initially classified NG-ZA-02, ZG-ZC-01, KNMA-01, and KN-GU-02 as resistance accessions on the field, were susceptible to the pathogen under screen house evaluation with severity score of 6.33, 4.33, 5.67 and 5.00, respectively. However, all the susceptible accessions used as check have a value of greater than five (5), with NGB501 having a severity score of 7.33 and KD-CK-01 with 5.33 (Table 3). 
MOLECULAR DIVERSITY IN SELECTED LANDRACES RESISTANCE TO BLAST PATHOGEN...

Table 2. Blast severity on 35 Pearl Millet accessions under field condition.

\begin{tabular}{|c|c|c|c|c|}
\hline Accessions & $\begin{array}{c}* \text { Disease } \\
\text { Scores }\end{array}$ & PDI & $\begin{array}{c}\text { Significant } \\
\text { Level }\end{array}$ & $\begin{array}{c}\text { Host } \\
\text { Reaction }\end{array}$ \\
\hline NGB501 & 4.60 & 57.50 & 0.063 & MS \\
\hline NGB514 & 5.20 & 65.00 & 0.136 & MS \\
\hline NGB523 & 7.33 & 82.50 & 0.064 & HS \\
\hline NGB528 & 7.44 & 83.75 & 0.150 & HS \\
\hline NGB571 & 2.20 & 27.50 & 0.088 & MR \\
\hline NGB575 & 6.50 & 81.25 & 0.121 & $\mathrm{~S}$ \\
\hline NGB578 & 6.10 & 76.25 & 0.083 & $\mathrm{~S}$ \\
\hline NGB589 & 3.10 & 38.75 & 0.059 & MR \\
\hline NGB594 & 4.44 & 50.00 & 0.063 & MS \\
\hline NGB606 & 3.50 & 43.75 & 0.077 & MR \\
\hline NG-ZA-01 & 4.40 & 55.00 & 0.063 & MS \\
\hline NG-ZA-02 & 3.00 & 37.50 & 0.059 & MR \\
\hline NG-ZA-05 & 5.90 & 73.75 & 0.083 & $\mathrm{~S}$ \\
\hline NG-ZA-08 & 1.90 & 23.75 & 0.060 & $\mathrm{R}$ \\
\hline NG-ZB-01 & 1.50 & 18.75 & 0.060 & $\mathrm{R}$ \\
\hline NG-ZB-03 & 6.20 & 77.50 & 0.083 & S \\
\hline NG-ZC-01 & 0.90 & 11.25 & 0.195 & HR \\
\hline NG-ZC-02 & 4.50 & 56.25 & 0.063 & MS \\
\hline NG-ZC-03 & 6.40 & 80.00 & 0.121 & MS \\
\hline KD-KG-01 & 4.70 & 58.75 & 0.136 & MS \\
\hline KD-CK-01 & 6.90 & 86.25 & 0.083 & $\mathrm{~S}$ \\
\hline KD-JB-01 & 7.70 & 96.25 & 0.064 & HS \\
\hline KD-JM-01 & 2.30 & 28.75 & 0.088 & MR \\
\hline NS-JIL-01 & 3.30 & 41.25 & 0.055 & MR \\
\hline NS-YEL-02 & 0.80 & 76.25 & 0.195 & HR \\
\hline NS-YEL-06 & 4.50 & 56.25 & 0.063 & MS \\
\hline NS-YEL-07 & 2.10 & 26.25 & 0.088 & MR \\
\hline NS-GAN-04 & 4.60 & 57.50 & 0.052 & MS \\
\hline NS-GAN-05 & 4.33 & 48.75 & 0.063 & MS \\
\hline NS-GIN-03 & 0.78 & 8.75 & 0.195 & HR \\
\hline KN-MA-01 & 2.00 & 25.00 & 0.088 & MR \\
\hline KN-GU-02 & 2.50 & 31.25 & 0.088 & MR \\
\hline JIG-DU-01 & 5.25 & 52.50 & 0.136 & MS \\
\hline JIG-BIR-01 & 4.78 & 53.75 & 0.136 & MS \\
\hline ZF-ZM-01 & 5.60 & 77.50 & 0.054 & MS \\
\hline Mean & 4.21 & 53.28 & & \\
\hline$\% \mathrm{CV}$ & 47.56 & 44.25 & & \\
\hline
\end{tabular}

Values are mean of 30 replicate samples. Disease score of $<1.0$ Highly Resistant (HR), 1.0-1.9 Resistant (R), 2.0-3.9 Moderately Resistant (MR), 4.0-5.0 Moderately Susceptible (MS), 5.1-7.0 Susceptible (S) and 7.1-9.0 Highly Susceptible (HS). PDI - Percentage Disease Incidence.

\section{Screen house evaluation for blast infection}

The result of screen house evaluation of the fourteen selected potential resistance and two susceptible (KD-CK-01 and NGB501) accessions as check is presented in Table 3. Out of the fourteen selected potential resistance accessions, nine (9) of the accession proved to be blast resistance with NS-YEL-02 being the most resistance to the pathogen with disease severity score of 0.00 when compared to the field value of 0.80 . This is followed by 
Abdulhakeem ABUBAKAR \& al.

accession NS-YEL-07 (0.67) and the least resistance being NS-JIL-01 with the value 3.33 compared to 3.30 on the field (Table 3). The initially classified NG-ZA-02, ZG-ZC-01, KNMA-01, and KN-GU-02 as resistance accessions on the field, were susceptible to the pathogen under screen house evaluation with severity score of 6.33, 4.33, 5.67 and 5.00, respectively. However, all the susceptible accessions used as check have a value of greater than five (5), with NGB501 having a severity score of 7.33 and KD-CK-01 with 5.33 (Table 3).

Table 3. Blast severity of selected Pearl Millet accession under artificial inoculation.

\begin{tabular}{lcccc}
\hline \multicolumn{1}{c}{ Accession } & \multicolumn{2}{c}{ Blast Severity } & \multicolumn{2}{c}{ Host Reaction } \\
& Field & Screen House & Field & Screen House \\
\hline *NGB501 & 4.60 & 7.33 & MS & HS \\
\hline NGB571 & 2.20 & 3.00 & MR & MR \\
\hline NGB589 & 3.10 & 2.33 & MR & MR \\
\hline NGB606 & 3.50 & 1.00 & MR & R \\
NG-ZA-02 & 3.00 & 6.33 & MR & S \\
\hline NG-ZA-08 & 1.90 & 3.67 & R & MR \\
\hline NG-ZB-01 & 1.50 & 0.33 & R & HR \\
\hline NG-ZC-01 & 0.90 & 4.33 & HR & MS \\
\hline KD-JM-01 & 2.30 & 1.00 & MR & R \\
\hline *KD-CK-01 & 6.90 & 5.33 & S & S \\
\hline NS-YEL-02 & 0.80 & 0.00 & HR & HR \\
\hline NS-YEL-07 & 2.10 & 0.67 & MR & HR \\
\hline NS-JIL-01 & 3.30 & 3.33 & MR & MR \\
\hline NS-GIN-03 & 0.78 & 3.18 & HR & MR \\
\hline KN-MA-01 & 2.00 & 5.67 & MR & S \\
\hline KN-GU-02 & 2.50 & 5.00 & MR & S \\
\hline
\end{tabular}

${ }^{*}=$ Susceptible check. Values are mean of 20 replicate samples. Disease score of $<1.0$

Highly Resistant (HR), 1.0-1.9 Resistant (R), 2.0-3.9 Moderately Resistant (MR), 4.0-5.0

Moderately Susceptible (MS), 5.1-7.0 Susceptible (S) and 7.1-9.0 Highly Susceptible (HS).

\section{Molecular analysis of selected accessions of pearl millet}

\section{RAPD primers performance and genetic diversity pattern}

Fifty nine (59) amplified fragment loci were generated with 10 DNA primers from the selected 16 accessions used (Figure 1, Table 4). Out of the 59 fragment amplified bands, 53 (89.83\%) were polymorphic and 6 (10.17\%) were monomorphic. Primers T17 had the highest polymorphic amplification fragment of 8 bands, and highest monomorphic amplification fragment of 2 bands was detected by primer $\mathrm{H} 10$ and primers T17. However, 100 percentage polymorphism was recorded from primer B08, primer H04, primer T10, primer T01, primer T06 and primer T05 with polymorphic information contentment (PIC) of $0.91,0.48,0.85,0.11,0.87$ and 0.87 , respectively. The PIC was in the range of $0.11-$ 0.91 with an average value of 0.72 (Table 4). However, there is no specific marker for resistant and susceptible accession to the disease. 


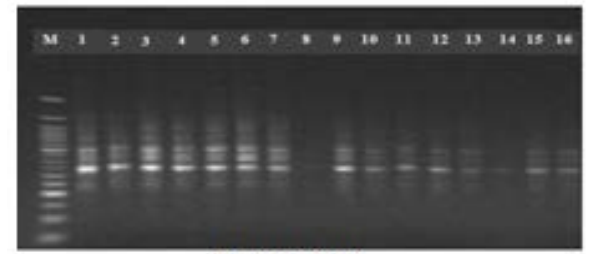

Primer B04

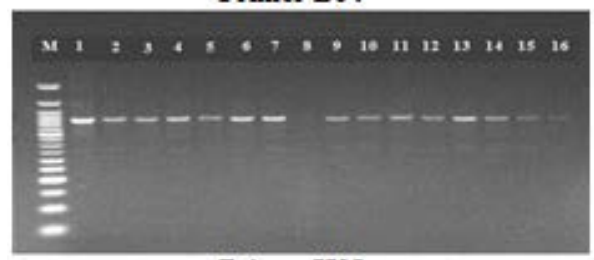

Primer $\mathrm{H} 08$

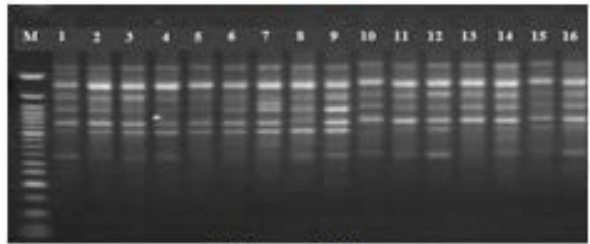

Primer H04

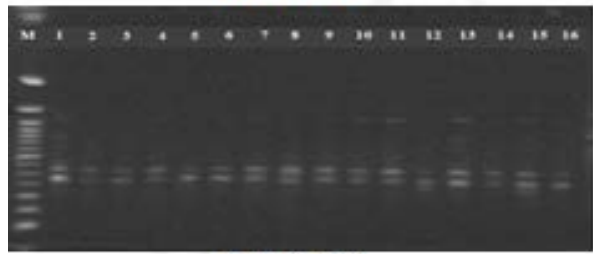

Primer T17

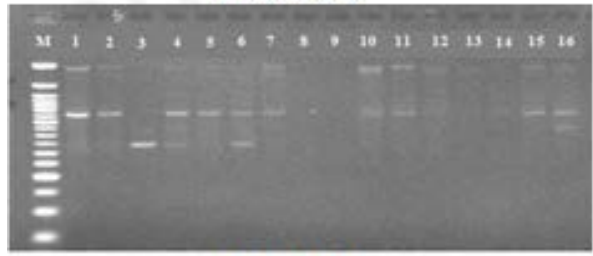

Primer T06

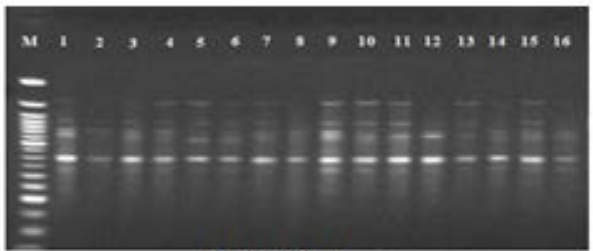

Primer B08

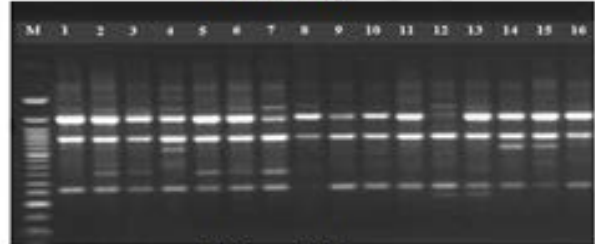

Primer Bl0

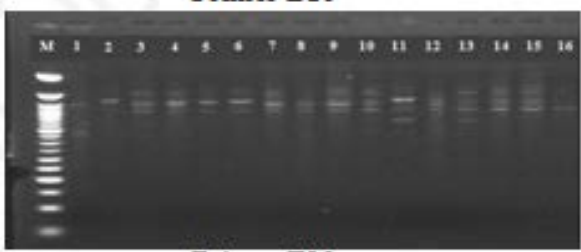

Primer T10

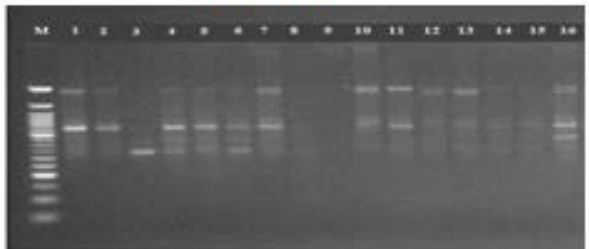

Primer T01

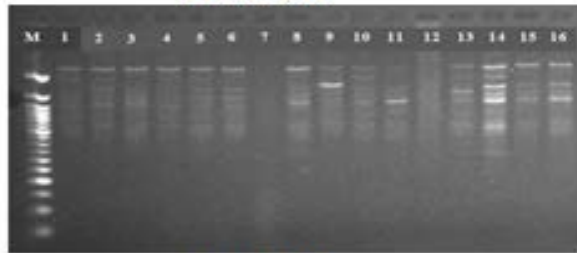

Primer T05

Figure 1. RAPD Amplification Patterns Using 10 Different DNA Primers.

$\mathrm{M}=$ ladder and number 1 to 16 on the first row represent the pearl millet accessions 1 NG-ZA-02, 2 NGB589, 3 NG-ZB-01, 4 KN-MA-01, 5 KN-GU-02, 6 NS-YEL-07, 7 NGZC-01, 8 NGB606, 9 KD-JM-01, 10 NG-ZA-08, 11 NS-YEL-02, 12 KD-CK-01, 13 NGB501, 14 NS-GIN-03, 15 NGB571, 16 NS-JIL-01. 
Abdulhakeem ABUBAKAR \& al.

Table 4. Sequencing and Polymorphic Information of ten RAPD DNA Markers for Pearl Millet.

\begin{tabular}{|c|c|c|c|c|c|}
\hline Marker & DNA Sequence & $\begin{array}{c}\text { Number of } \\
\text { Monomorphic } \\
\text { Band } \\
\end{array}$ & $\begin{array}{c}\text { Number of } \\
\text { Polymorphic } \\
\text { Band } \\
\end{array}$ & $\begin{array}{c}\text { Percentage } \\
\text { Polymorphic } \\
\text { Bands } \\
\end{array}$ & PIC \\
\hline primer B04 & $5^{1}-$ GGA CTG GAG T - $3^{1}$ & 1.00 & 6.00 & 85.71 & 0.86 \\
\hline primer B08 & $5^{1}-$ GTG CAC ACG G - $3^{1}$ & 0.00 & 6.00 & 100.00 & 0.91 \\
\hline Primer H08 & $5^{1}-$ GAA ACA CCC C- $3^{1}$ & 1.00 & 6.00 & 85.71 & 0.85 \\
\hline primer H10 & $5^{1}-\mathrm{CCT}$ ACG TCA G - $3^{1}$ & 2.00 & 3.00 & 60.00 & 0.54 \\
\hline primer H04 & $5^{1}-$ GGA AGT CGC C - $3^{1}$ & 0.00 & 4.00 & 100.00 & 0.48 \\
\hline primer $\mathrm{T} 10$ & $5^{1}-$ CCT TCG GAA G - $3^{1}$ & 0.00 & 7.00 & 100.00 & 0.85 \\
\hline primer T17 & $5^{1}-$ CCA ACG TCG T - $3^{1}$ & 2.00 & 8.00 & 80.00 & 0.90 \\
\hline primer T01 & $5^{1}-$ GGG CCA CTC A - $3^{1}$ & 0.00 & 1.00 & 100.00 & 0.11 \\
\hline primer T06 & $5^{1}-\mathrm{CAA}$ GGG CAG A - $3^{1}$ & 0.00 & 6.00 & 100.00 & 0.87 \\
\hline primer T05 & $5^{1}-$ GGG TTT GGC A - $3^{1}$ & 0.00 & 6.00 & 100.00 & 0.87 \\
\hline Mean & & 0.60 & 5.30 & 91.14 & 0.72 \\
\hline
\end{tabular}

A total of 88 alleles were generated by the 10 primer used, with the number of allele per primers ranges from 2.00 to 13.00 and overall average value of 8.80 . Primer T17 had highest number of alleles (13.00) and primers T01 had the lowest with the value of 2.00 (Table 5). The major allelic frequency was highest in primer T01 (0.94) and the least was obtained from primer B08 with the values 0.13 . Gene diversity ranged from $0.12-0.91$ with a mean value of 0.74 . The highest gene diversity (0.91) was generated by both primerB08 and primer T17, followed by primer T06 and primer T05 both with gene diversity of 0.88 and the least was recorded in primer T01 with the value of 0.12 . With the exception of primer H10, primer $\mathrm{H} 04$ and primer T01, the gene diversity generated from each accession was higher than the overall average value of 0.74 (Table 5).

\section{Dissimilarity and cluster analysis of pearl millet accession}

The genetic similarity among the sixteen accessions of pearl millet varied between 0.18 and 1.44 . The lowest similarity of 0.18 was for KN-MA-01 and KN-GU-02, and highest similarity of 1.44 was due to NGB606 and NG-ZA-08. The genetic similarity between KD-CK-01 and NGB501 was 0.29, but wide apart from all other accessions (Table 6). The UPGMA dendrogram generated from the 16 accessions revealed two major cluster groups (Figure 2). The first cluster (Group A) consisted of two susceptible accessions (KDCK-01 and NGB501) with similarity coefficient 1.14. The second cluster group B, consist of all the 14 selected resistant accessions with only NS-YEL-02 sub-clustered in BI as a unique accession. Sub-clustered group BII, had the highest number of 13 accessions equivalent to $81.25 \%$ of the total selected accession and further sub-divided into two subgroups (C1 and C2) with similarity coefficient of 0.02. Sub-cluster C1 had accession two accessions (NG-ZA-08 and NS-JIL-01) with similarity coefficient value of 1.10. Subcluster C2 was further grouped into two sub-sub groups (C2a and C2b) with 6 accessions (KN-GU-02, NS-YEL-07, NG-ZC-01, KN-MA-01, NG-ZA-02 and NGB589) and 5 accessions (NG-ZB-01, NGB606, KD-JM-01, NS-GIN-03 and NGB571) respectively at 
similarity distance coefficient of 0.01 . However, the blast resistant accession NS-YEL-07 (Presented earlier in Table 3) was cluster in C2aI alongside with the susceptible accessions under the screen house conditions, while NG-ZA-02 and NGB589 were clustered together in a distinct group (C2aII). Cluster C2bI were all resistant accessions, with the high resistant accession NG-ZB-01 having the highest similarity distance coefficient (1.11) from its closest relative (Figure 2). This is an indication that RAPD molecular marker is an excellent tool in identifying and characterizing blast resistant and susceptible genotypes.

Table 5. Numbers of alleles, frequency and gene diversity of ten RAPD markers for Pearl Millet.

\begin{tabular}{lcccccc}
\hline Marker & $\begin{array}{c}\text { Sample } \\
\text { size }\end{array}$ & $\begin{array}{c}\text { Number of } \\
\text { observable }\end{array}$ & Availability & $\begin{array}{c}\text { Allele } \\
\text { number }\end{array}$ & $\begin{array}{c}\text { Major Allelic } \\
\text { frequency }\end{array}$ & $\begin{array}{c}\text { Gene } \\
\text { diversity }\end{array}$ \\
\hline primer B04 & 16.00 & 16.00 & 1.00 & 11.00 & 0.25 & 0.88 \\
primer B08 & 16.00 & 16.00 & 1.00 & 13.00 & 0.13 & 0.91 \\
primer H08 & 16.00 & 16.00 & 1.00 & 10.00 & 0.25 & 0.87 \\
primer H10 & 16.00 & 16.00 & 1.00 & 5.00 & 0.63 & 0.57 \\
primer H04 & 16.00 & 16.00 & 1.00 & 4.00 & 0.63 & 0.54 \\
primer T10 & 16.00 & 16.00 & 1.00 & 10.00 & 0.25 & 0.86 \\
primer T17 & 16.00 & 16.00 & 1.00 & 13.00 & 0.19 & 0.91 \\
primer T01 & 16.00 & 16.00 & 1.00 & 2.00 & 0.94 & 0.12 \\
primer T06 & 16.00 & 16.00 & 1.00 & 10.00 & 0.19 & 0.88 \\
primer T05 & 16.00 & 16.00 & 1.00 & 10.00 & 0.19 & 0.88 \\
Mean & 16.00 & 16.00 & 1.00 & 8.80 & 0.36 & 0.74 \\
\hline
\end{tabular}

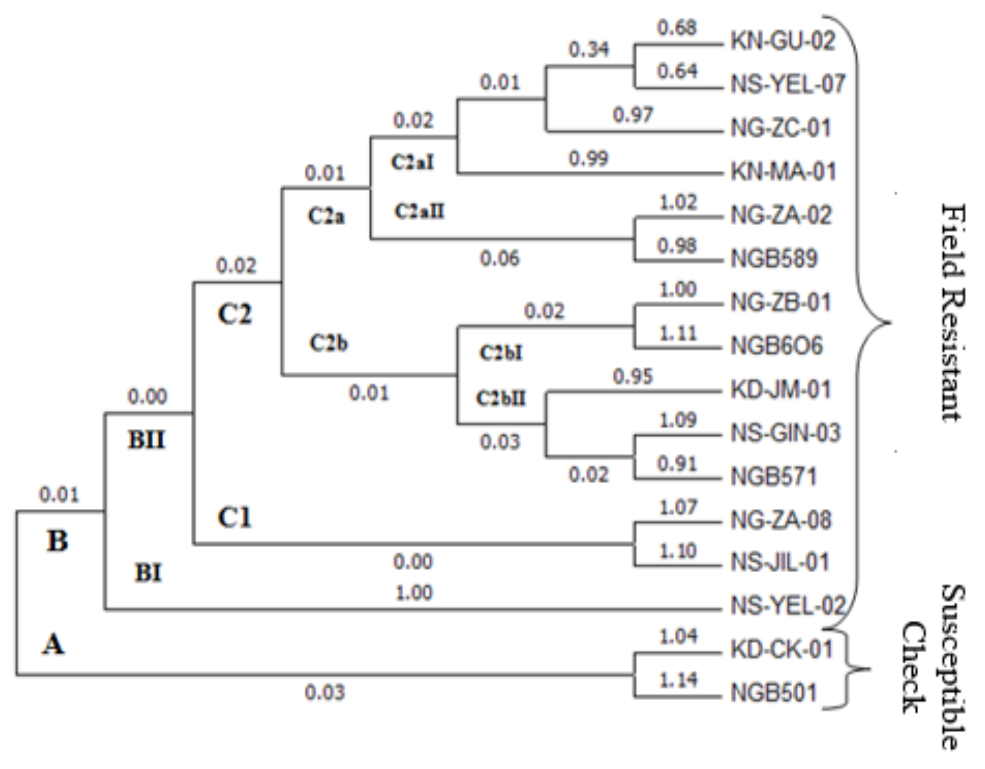

Figure 2. Dendrogram of genetic diversity of selected accessions of Pearl Millet. 
Abdulhakeem ABUBAKAR \& al.

Table 6. Dissimilarity matrix of sixteen (16) selected Pearl Millet accessions

\begin{tabular}{|c|c|c|c|c|c|c|c|c|c|c|c|c|c|c|c|c|}
\hline $\mathrm{X}$ & 1 & 2 & 3 & 4 & 5 & 6 & 7 & 8 & 9 & 10 & 11 & 12 & 13 & 14 & 15 & 16 \\
\hline 1 & 0.00 & & & & & & & & & & & & & & & \\
\hline 2 & 0.23 & 0.00 & & & & & & & & & & & & & & \\
\hline 3 & 0.43 & 0.39 & 0.00 & & & & & & & & & & & & & \\
\hline 4 & 0.29 & 0.26 & 0.21 & 0.00 & & & & & & & & & & & & \\
\hline 5 & 0.47 & 0.29 & 0.36 & 0.18 & 0.00 & & & & & & & & & & & \\
\hline 6 & 0.52 & 0.32 & 0.26 & 0.26 & 0.09 & 0.00 & & & & & & & & & & \\
\hline 7 & 0.52 & 0.39 & 0.47 & 0.26 & 0.29 & 0.32 & 0.00 & & & & & & & & & \\
\hline 8 & 0.94 & 0.57 & 0.47 & 0.84 & 0.94 & 0.68 & 0.84 & 0.00 & & & & & & & & \\
\hline 9 & 0.47 & 0.52 & 0.23 & 0.36 & 0.47 & 0.36 & 0.36 & 0.76 & 0.00 & & & & & & & \\
\hline 10 & 0.36 & 0.57 & 0.57 & 0.39 & 0.52 & 0.57 & 0.32 & 1.44 & 0.36 & 0.00 & & & & & & \\
\hline 11 & 0.29 & 0.47 & 0.47 & 0.39 & 0.36 & 0.39 & 0.47 & 0.68 & 0.43 & 0.26 & 0.00 & & & & & \\
\hline 12 & 0.52 & 0.68 & 0.39 & 0.57 & 0.94 & 0.84 & 0.47 & 0.68 & 0.52 & 0.47 & 0.26 & 0.00 & & & & \\
\hline 13 & 0.47 & 0.62 & 0.62 & 0.62 & 0.68 & 0.62 & 0.43 & 0.62 & 0.57 & 0.36 & 0.29 & 0.29 & 0.00 & & & \\
\hline 14 & 0.57 & 0.52 & 0.62 & 0.62 & 1.07 & 0.76 & 1.23 & 0.52 & 0.39 & 0.52 & 0.43 & 0.76 & 0.68 & 0.00 & & \\
\hline 15 & 0.43 & 0.39 & 0.39 & 0.32 & 0.43 & 0.39 & 0.57 & 0.68 & 0.23 & 0.47 & 0.32 & 0.39 & 0.62 & 0.23 & 0.00 & \\
\hline 16 & 0.26 & 0.43 & 0.43 & 0.43 & 0.47 & 0.62 & 0.43 & 1.23 & 0.47 & 0.29 & 0.29 & 0.43 & 0.57 & 0.57 & 0.43 & 0.00 \\
\hline
\end{tabular}

\section{Discussion}

Effective resistance breeding programmes require close monitoring of virulence changes in the pathogen and identification of new resistance sources to the virulent strains [THAKUR \& al. 2009a]. Identification of fourteen (14) potential resistant genotypes under natural field condition and the confirmation of ten (10) of the genotypes under artificial screen house condition indicated that sources of resistance genotype(s) to blast pathogen in pearl millet could be obtained from the natural eco-type Germplasm and landraces. The variability in the level of resistance of the plants may be attributed to either their anatomical and/or genetical characters, which prevented the pathogen from penetrating and causing infection in the leaves. This result is in agreement with the work of SHANMUGAPACKIAM \& RAGUCHANDER (2018), they identified 32 germplasm accessions from the mini-core collection having resistance to at least one of the five pathotypes of Magnaporthe grisea in India. According to WILSON \& HANNA (1992), resistance expression in pearl millet to Pyricularia leaf spot has a tendency to be dominant or partially dominant. The susceptibility of some of the field potential resistance accessions to the pathogen under artificial screening, indicate their opportunistic resistance and could be favoured by the prevailing environmental condition at that period. This conformed to the report of THAKUR \& al. (2009b), that screening under natural infection condition may give room for escapes, with variation in the level occurrence of the disease severity from season to season, thereby complicating the identification of the true resistance genotypes. It has been documented that with proper management of the crop, most diseases can escape or withstand with insignificant impact on yield [KHAIRWAL \& al. 2007]. Also, in accordance 
with these statements THAKUR \& al. $(2008,2009)$ reported that under natural ecosystems, factors such as environmental variables, inoculum load and agronomic practices greatly influenced host-pathogen interaction thus, optimal for disease development and variation in the resistance of the cultivar.

The average polymorphic bands of 5.30 per primer obtained in this study was similar to 5.35 polymorphic bands per primer reported among 36 cultivars of six major cereal crops by CHAUHAN \& al. (2015). These values were lower than the 6.30 of polymorphic band per primer reported by MOHAMMED \& HAMZA (2018) using 40 accessions of pearl millet from Sudan and higher than 4.40 per primer reported by NWEKE (2014), who evaluated genetic diversity in 10 genotypes of pearl millet for drought tolerance using RAPD technique. The slight difference recorded among the results could be attributed to the variation in the number of sample used in the various studies. The mean polymorphic information content (PIC) of 0.72 obtained for all the RAPD markers used, indicate the effectiveness of the markers. AHMAD \& al. (2015), reported that marker is effective if the PIC value is higher than 0.5 . The ranged of polymorphic information content (0.48 - 0.91) recorded in the present study fall within the range of $0.48-0.76$ reported by BENEDICT \& al. (2016), 0.05 to 0.96 by KAPILA \& al. (2008) using SSR markers.

According to PFEIFFER \& al. (2011), higher number of alleles and high polymorphism are very important for correct estimation of genetic diversity of a germplasm and effectiveness of markers development, construction of segregating populations and provides enriched gene resources for gene mining in the grass family [WANG \& al. 2012]. The high number of allelic mean (8.80) and wide range of gene diversity $(0.12-0.91)$ with average value of 0.71 generated by the primers for the selected accessions indicate the level of diversity among the accession and reliability of the primers. The obtained mean value, agreed with the value of 0.74 across west and central pearl millet inbreds reported by STICH \& al. (2010), 0.77 for Sudanese cultivated accessions [BASHIR \& al. 2014], using SSR markers but, higher 0.49 among landraces from Niger [MARIAC \& al. 2006] and 0.41 obtained for the 114 cultivated accessions from Benin, 0.49 in the cultivated [BENEDICT \& al. 2016] using SSR markers. Thus, Nigeria and Sudan are probably the centres of origin of pearl millet.

The high polymorphic information content alongside with high gene diversity generated by the primers from the accession could be attributed to the free cross pollination of the species which result in high reshuffling of genes and its heterozygosity. This assertion is in line with the Hardy and Weinberg equilibrium principle which assumed that randomized mating population system result in heterozygosity of gene. In conformity with this statement, MOHAMMED \& HAMZA (2018), opined that for pearl millet landraces, heterogeneity and heterozygosity at many loci within the accession is expected to be high due to the cross-pollinated nature of the crop, and their protogynous flowering behavior [ANIMASAUN \& al. 2015]. The wide range of dissimilarity distance obtained in this study could be attributed to the difference in the geographic origin and pedigrees. However, pedigree information or geographic origins of cultivars may not accurately reflect the genetic relatedness among genotypes, whereas DNA markers could do when sufficient markers used are distributed across all chromosomes [ZHANG \& al. 2005].

Information on genetic diversity and relationship among breeding materials in any germplasm collection had been reported to be important in identification of cultivars and selection of parents for hybridization, as well as predicting favorable heterotic combinations [KITAVI \& al. 2014]. The clusters of accessions into resistant and susceptible 
Abdulhakeem ABUBAKAR \& al.

group indicate that random amplified polymorphic DNA (RAPD) markers could serve as selectable marker in pearl millet. This clustering of the accessions could be attributed to the presence of monogenetic disease resistance gene in pearl millet for blast as earlier shown by preliminary investigation of GUPTA \& al. (2012), that pearl millet had single dominant gene for resistance to blast disease. In contrast to the result of this study, KITAVI \& al. (2014) reported that distribution of species in a cluster is usually based on the spatial structure of the genetic variation across their geographical region. The variation among these reports could be due the differences in the sample size of the accessions used and number of primers. In line with these statements, YOUNG \& KELLY (1996) had earlier reported that molecular markers such as RAPD, has the potential to serves as selectable marker where monogenic disease resistance genes have been identified. Identification of RAPD markers tightly linked to resistance genes has been reported to be important in selection of the resistance gene indirectly, since the expression of the molecular marker is not masked by epistatic interactions that take place between resistance genes [KELLY, 1995]. Similar to the observation of MAHATMA \& al. (2011), the RAPD analysis does not link any specific marker for disease resistant and susceptible landraces. The non-specificity of any of the marker indicates their non-reliability for selection of resistance gene(s). The clusters of accessions from different state and sources in the same group by RAPD markers confirmed that there was no association between pattern of clusters and geographical distribution of accessions in this population. BENEDICT \& al. (2016) attributed this clustering of accessions to wide germplasm exchange that occurs between farmers from different environment and even among regions due to the dependent of some regions on the main producers of the crop for their seeds. The result obtained further buttressed the fact that RAPD molecular marker is an excellent molecular tool in evaluating the genetic diversity among pearl millet accessions.

\section{Conclusions}

Considerable high variability exists among landraces of pearl millet in Nigeria from which resistance genotype(s) to blast pathogen could be obtained. Variation in the resistance and susceptibility of the accessions both on the field and nursery screening, demonstrated the inherent resistant potentials of some accessions as sources of resistance to blast disease. Based on the resistance capability, NS-YEL-02 could be selected as elite parent genotype in blast disease resistance breeding programs of pearl millet. Clustering of the selected landraces base on resistance and susceptibility by RAPD techniques, indicate its possibility for indirect selection of blast resistant genotypes for the crop. However, further genotyping is needed to identify the blast resistance gene(s) in the crop.

\section{Notes on contributors}

Abdulhakeem ABUBAKAR is a lecturer in Plant Biology Department with specialization in plant Genetics and breeding. His research areas of interest are: improvement of tropical plants and plant fungi disease management.

Olamide Ahmed FALUSI is a professor in the Department of Plant Biology. His research focuses on crop improvement and cytogenetic.

Matthew Omoniyi ADEBOLA is Associate professor of plant biology with specialization in plant pathology (Mycology). His research focuses in the plant diseases management and control.

Oladipupo Abdulazeez Yusuf DAUDU is a plant geneticist/breeder with a special interest in genetic improvement of tropical crop.

Amina Jummai SALAUDEEN is a research scientists with interest in crop protection. 


\section{References}

ABDULLAHI A. B., IHEANACHO A. C. \& IBRAHIM A. 2006. Econometric analysis of the relationship between drought and millet production in the arid zone of Nigeria: A case study of Borno and Yobe states. Journal of Agriculture \& Social Sciences. 2(3): 170-174.

ABOU-TALEB E. M., ABOSHOSHA S. M., EL-SHERIF E. M. \& EL-KOMY M. H. 2010. Genetic diversity among late blight resistant and susceptible potato genotypes. Saudi Journal of Biological Sciences. 17: 133-138.

AHMAD F., HANAFI M. M., HAKIM M. A., RAFII M. Y., AROLU I. W. \& ABDULLAH A. S. N. 2015. Genetic divergence and heritability of 42 coloured upland rice genotypes (Oryza sativa) as revealed by microsatellites marker and agro-morphological traits. PLOS ONE. 10(9): e0138246. https://doi.org/10.1371/journal.pone.0138246.

ANGARAWAI I. I., ALADELE S., DAWUD M. A., TURAKI Z. G. S. \& YAKUB Y. 2016. Genetic Diversity among Nigeria 'Maiwa Type' of Pearl Millet Germplasm. Global Journal of Science Frontier Research. 16(3): 14-20.

ANIMASAUN D. A., MORAKINYO J. A., MUSTAPHA O. T. \& KRISHNAMURTHY R. 2015. Assessment of genetic diversity in accessions of pearl millet (Pennisetum glaucum) and napier grass (Pennisetum purpureum) using microsatellite (ISSR) markers. Iranian Journal of Genetics and Plant Breeding. 4(1): 25-35.

AZARE I. M., DANTATA I. J., ABDULlAHI M. S., ADEBAYO A. A. \& ALIYU M. 2020. Effects of Climate Change on Pearl Millet (Pennisetum glaucum [L. R. Br.]) production in Nigeria. Journal of Applied Sciences and Environmental Management. 24(1): 157-162.

BASHIR E. M. A., ABDELBAGI M. A., ADAM M. A., ALBRECHT E. M., HEIKO K. P. \& HAUSSMANN B. I. G. 2014. Characterizations of Sudanese pearl millet germplasm for agro-morphological traits and grain nutritional values. Plant Genetic Resources. 12: 35-47.

BENEDICT B. M., CHIMWAMUROMBE P., KWEMBEYA E. \& MAGGS-KÖLLING G. 2016. Genetic diversity of Namibian Pennisetum glaucum (L.) R. Br. (pearl millet) landraces analyzed by SSR and morphological markers. World Journal: 1-11. https://doi.org/10.1155/2016/1439739

CHAUHAN R., JASRAI Y., MANKAD A., PANDYA H. \& GAMI R. 2015. Genetic Diversity Analysis of Six Major Cereal Crops Cultivars through RAPD Markers. Advances in Crop Science and Technology. 3(4): 1-4.

DAUDU O. A. Y, FALUSI O. A., GANA S. A., ABUBAKAR A., OLUWAJOBI A. O., DANGANA M. C. \& YAHYA S. A. 2016. Assessment of genetic diversity among newly selected roselle (Hibiscus sabdariffa Linn.) genotypes in Nigeria using RAPD-PCR molecular analysis. World Journal of Agricultural Research. 4(3): 64-69. https://doi.org/10.12691/wjar-4-3-1

GUPTA N., SRIVASTAVA A. K. \& PANDEY V. N. 2012. Biodiversity and nutraceutical quality of some indian millets. Proceedings of the National Academy of Sciences, India, Section B: Biological Science. https://doi.org/10.1007/s40011-012-0035-z

KAPILA R. K., YADAV R. S., PLAHA P., RAI K. N., YADAV O. P., HASH C. T. \& HOWARTH C. J. 2008. Genetic diversity among pearl millet maintainers using microsatellite markers. Plant Breeding. 127: 33-37.

KELLY J. D. 1995. Use of Random Amplified Polymorphic DNA Markers in Breeding for Major Gene Resistance to Plant Pathogens. HortScience. 30(3): 461-462.

KHAIRWAL I. S., YADAV S. K., RAI K. N., UPADHYAYA H. D., KACHHAWA D., NIRWAN B., BHATTACHARJEE R., RAJPUROHIT B. S., DANGARIA C. J.\&SRIKANT. 2007. Evaluation and identification of promising pearl millet germplasm for grain and fodder traits. Journal of SAT Agricultural Research. 5(1): 6-12.

KITAVI M. N., KIAMBI D. K., HAUSSMAN B., SEMAGN K., MULUVI G., KAIRICHI M. \& MACHUKA J. 2014. Assessment of the genetic diversity and pattern of relationship of West African sorghum accessions using microsatellite markers. African Journal of Biotechnology. 13(14): 1503-1514.

LUBADDE G., TONGOONA P., DERERA J. \& SIBIYA J. 2014. Major pearl millet diseases and their effects on farm grain yield in Uganda. African Journal of Agricultural Research. 9(39): 2911-2918. https://doi.org/10.5897/AJAR2013.7208

MAHATMA M. K., BHATNAGAR R., SOLANKI R. K., MITTAL G. K. \& SHAH R. R. 2011. Characterizations of downy mildew resistant and susceptible pearl millet (Pennisetum glaucum (L.) R. Br.) genotypes using isozyme, protein, randomly amplified polymorphic DNA and inter-simple sequence repeat markers. Journal Archives of Phytopathology and Plant Protection. 44(20): 1985-1998. 
Abdulhakeem ABUBAKAR \& al.

MANANDHAR H. K., TIMILA R. D., SHARMA S., JOSHI S., MANANDHAR S., GURUNG S. B. \& STHAPIT B. R. 2016. A field guide for identification and scoring methods of diseases in the mountain crops of Nepal. Maccarese, Rome, Italy, Biodiversity International, 133-135 pp.

MARIAC C., LUONG V., KAPRAN I., MAMADOU A., SAGNARD F., DEU M., CHANTEREAU J., GERARD B., NDJEUNGA J., BEZANCON G., PHAM J. L. \& VIGOUROUX Y. 2006. Diversity of wild and cultivated pearl millet accessions (Pennisetum glaucum (L.) R. Br.) in Niger assessed by microsatellite markers. Theoretical of Applied Genetics. 114: 49-58.

MOHAMMED H. I. \& HAMZA N. B. 2018. Genetic diversity analysis of forty Pearl Millet (Pennisetum glaucum (L.) R. Br.) accessions from Sudan using agronomical descriptors and DNA molecular markers. Advances in Bioscience and Biotechnology. 9: 322-337.

MONDAL S., GHOSH S. \& BADIGANNAVAR A. M. 2005. RAPD polymorphism among Groundnut genotypes differing in disease reaction to late leaf spot and rust. Biotechnology. 25: 27-30.

NWEKE O. 2014. Evaluation of genetic diversity in pearl millet (Pennisetum glaucum (L.) R. Br.) genotypes for drought tolerance using RAPD technique. MSc dissertation, Ahmadu Bello University, Zaria, Nigeria.

OBIDIEGWU O. N., PARZIES H. \& OBIDIEGWU J. E. 2014. Development and genotyping potentials of ESTSSRs in Finger Millet (E. coracana (L.) Gaertn.). International Journal of Genetics and Genomics. 2(3): 42-46.

PAWAR V. Y., KUTE N. S., DESHMUKH G. P., PATIL H. T., AWARI V. R. \& MAGAR N. M. 2016. Inheritance of blast resistance in pearl millet (Pennisetum glaucum L.). Electronic Journal of Plant Breeding. 7(4): 877-882.

PFEIFFER T., ROSCHANSKI A. M., PANNELL-KORBECKA G. \& SCHNITTER M. 2011. Characterization of microsatellite loci and reliable genotyping in a polyploidy plant, Mercurialis perennis (Euphorbiaceae). The Journal of Heredity. 102: 479-488.

SHAH I. A., RAHMAN H. U., SHAH S. M. A., SHAH Z., RAHMAN S., IHTERAMULLAH S. \& NOOR M. 2012. Characterization of pearl millet germplasm for various morphological and fodder yield parameters. Pakistan Journal of Botany. 44(1): 273-279.

SHANMUGAPACKIAM S. \& RAGUCHANDER T. 2018. Host range and cross infectivity of the genus Magnaporthe grisea. International Journal of Current Microbiology and Applied Sciences. 7(8): 39503955.

SHARMA R., UPADHYAYA H. D., MANJUNATHA S. V., RAI K. N., GUPTA S. K. \& THAKUR R. P. 2013. Pathogenic variation in the Pearl Millet blast pathogen Magnaporthe grisea and identification of resistance to diverse pathotypes. Plant Disease. 97(2): 189-195.

SINGH A. K., RANA M. K., SINGH S., KUMAR S., DURGESH K. \& ARYA L. 2013. Assessment of genetic diversity among pearl millet (Pennisetum glaucum (L.) R. Br.) cultivars using SSR markers. Range Management and Agroforestry. 34(1): 77-81.

STICH B., HAUSSMANN B. I. G., PASAM R., BHOSALE S., HASH C. T., MELCHINGER A. E. \& PARZIES H. K. 2010. Patterns of molecular and phenotypic diversity in pearl millet [Pennisetum glaucum (L.) R. $\mathrm{Br}$.] from West and Central Africa and their relation to geographical and environmental parameters. BMC Plant Biology. 10(1): 216 - 226.

TAMURA K., STECHER G., PETERSON D., FILIPSKI A. \& KUMAR S. 2013. MEGA6: Molecular evolutionary genetics analysis version 6.0. Molecular Biology and Evolution. 30: 2725-2729.

THAKUR R. P., SHARMA R. \& RAO V. P. 2011. Screening techniques for Pearl Millet diseases. Information Bulletin, 89, Patancheru 502 324, Andhra Pradesh, India: International Crops Research Institute for the Semi-Arid Tropics. 15-19 pp.

THAKUR R. P., RAO V. P. \& SHARMA R. 2009a. Temporal virulence change and identification of resistance in pearl millet germplasm to diverse pathotypes of Sclerospora graminicola. Journal of Plant Pathology. 91(3): 629-636. https://doi.org/10.4454/jpp.v91i3.554

THAKUR R. P., SHARMA R., RAI K. N., GUPTA S. K. \& RAO V. P. 2009b. Screening techniques and resistance sources for foliar blast in pearl millet. Journal of SAT Agricultural Research. 7: 1-5.

THAKUR R. P., RAI K. N., KHAIRWAL I. S. \& MAHALA R. S. 2008. Strategy for downy mildew resistance breeding in pearl millet in India. Journal of SAT Agricultural Research. 6: 1-11.

WANG C., JIA G., ZHI H., NIU Z., CHAI Y., LI W., WANG Y., LI H., LU P., ZHAO B. \& DIAO X. 2012. Genetic diversity and population structure of chinese foxtail millet [Setaria italica (L.) Beauv.] landraces. G3 Genes Genomes Genetics. 2: 769-777.

WILliAMS J. G. K., KUBELIC A. R., LIVAK K. J., RAFALSKI J. A. \& TINGEY S. V. 1990. DNA polymorphisms amplified by arbitray primers are useful as genetic markers. Nucleic Acids Research. 18(2): 6531-6535. https://doi.org/10.1093/nar/18.22.6531

WILSON J. P. \& HANNA W. W. 1992. Effects of gene and cytoplasm substitutions in pearl millet on leaf blight epidemics and infection by Pyricularia grisea. Phytopathology. 82: 839-842. 
YOUNG R. A. \& KELLY J. D. 1996. RAPD markers flanking the ARE gene for anthracnose resistance in common bean. Journal of the American Society for Horticultural Science. 121(1): 37-41.

ZHANG J. F., LU Y., CANTRELL R. G. \& HUGHS E. 2005. Molecular marker diversity and field performance in commercial cotton cultivars evaluated in the Southwest U.S. Crop Science. 45: 1483-1490.

How to cite this article:

ABUBAKAR A., FALUSI O. A., ADEBOLA M. O., DAUDU O. A. Y. \& SALAUDEEN A. J. 2020. Molecular diversity in selected landraces resistance to blast pathogen (Pyricularia grisea Cooke ex Sacc.) of pearl millet (Pennisetum glaucum (L.) R. Br.) germplasm from Northern Nigeria. J. Plant Develop. 27: 159174. https://doi.org/10.33628/jpd.2020.27.1.159 